\title{
Preferences for the forms of co-payment and advance payment in healthcare services; a discrete choice experiment
}

\author{
Masaki Okuda ${ }^{1)}$, Yukinobu Ichida ${ }^{2)}$, Keita Yamane ${ }^{3)}$, Rika Ohtsuka ${ }^{4}$, \\ Miwa Yamaguchi ${ }^{5)}$, Rei Goto ${ }^{6)}$, Atsuhiro Yamada ${ }^{7}$, \\ Atsushi Sannabe ${ }^{8)}$, Naoki Kondo ${ }^{9)}$, Takashi Oshio ${ }^{10)}$
}

\begin{abstract}
In Japan, households receiving welfare benefits are not required to pay for medical services that fall within the scope of their assistance programme. The payment obligations for other low-income households may also be limited because the public health insurance system provides services in-kind. It has been argued, therefore, that these features may contribute to an increase in the nation's healthcare expenditure. However, no strong evidence has been presented so far to support this argument.

This study conducted a conjoint analysis based on an online questionnaire survey of households on welfare and other low-income households in general to examine how their use of medical services may be affected if they are required to make co-payments, if their co-payments rise, or if a reimbursement system is adopted. The survey participants are 2,600 people, 458 of whom are from households on welfare (as representatives of all households nationwide that are receiving welfare assistance), 1,542 from other low-income households, and 600 from middleincome households (with annual income between 6 and 12 million yen).

The analysis has shown that, in general, an increase in co-payments would discourage people from seeking medical care. However, this relationship was not observed among middle-income households in the case of treatment of children's cavities.

Under a system in which patients first pay all the medical expenses in advance and later receive reimbursements, households on welfare and other low-income households in general would be less likely than middle-income households to seek medical care. Such a system would discourage welfare recipients and low-income people from seeking treatment for various medical conditions that they themselves may have and for two specific types of conditions that their children may experience, namely, rough skin and vomiting. However, it would not discourage them from seeking treatment for children's high fevers or cavities, except in the case of cavities in children of low-income parents.
\end{abstract}

1) Executive and Chief Consultant, Doctoral Institute for Evidence Based Policy

2) Chief Executive Officer, Doctoral Institute for Evidence Based Policy

3) Part-time Lecturer, Faculty of Economics, Niigata Sangyo University

4) Researcher, Disaster Resilience Research Div., National Research Institute for Earth Science and Resilience

5) Section Head, Section of International Nutrition Strategy, International Center for Nutrition and Information, National Institute of Health and Nutrition, National Institutes of Biomedical Innovation, Health and Nutrition

6) Associate Professor, Graduate School of Business Administration, Keio University

7) Professor of Social Policy, Faculty of Economics, Keio University

8) Associate Professor, Department of Economics, Ryutsu Keizai University

9) Professor, Department of Social Epidemiology, School of Public Health, Kyoto University

10) Professor, Institute of Economic Research, Hitotsubashi University 
The analysis shows that, if a reimbursement system is adopted, people in low-income households in particular would become less eager to seek treatment for their own medical conditions, including conditions for which treatment is highly necessary. Thus, such findings should be taken into consideration when discussing whether to introduce a reimbursement system.

[Keywords] medical-care demand, welfare, reimbursement, online survey, conjoint analysis

\section{Introduction}

Under Japanese public health insurance system, the basic form of user charge is co-insurance rate. Patients, in principle, pay between $10 \%$ and $30 \%$ of the medical expenses, with the rest paid by the insurance programme to which they belong and by tax-based public funds (Note 1). Meanwhile, people in households that receive welfare benefits (seikatsu hogo) under a system designed to guarantee "minimum standards of wholesome and cultured living' in accordance with the severity of their hardship_also receive medical assistance (iryo fujo), in addition to living and housing allowances. Under this medical assistance programme, welfare recipients do not have to pay medical expenses if they are not receiving any other medical assistance and if the local welfare office determines that such assistance is necessary, the national and local governments will shoulder all the expenses if eligible individuals submit the necessary applications.

Such a system raises the concern that people eligible for free medical assistance and those whose co-payments are low may seek medical care beyond the "true" levels of needs based on the patients' health conditions. In fiscal year 2016, the nation spent a total of 3.7 trillion yen on welfare assistance, of which 1.7 trillion yen were allocated to medical assistance (according to a report on welfare assistance payments released by the Ministry of Health, Labour, and Welfare). The amount has been rising as welfare recipients continue to age. Thus, measures are being implemented to discourage people from making unnecessary visits to physicians, with some people advised to seek medical attention less frequently. The economy generally works in such a way that a price increase leads to a decline in demand for nonessential medical services. However, there are concerns that an increase in copayments would have negative consequences. For example, such an increase would make it difficult for socially vulnerable people, such as low-income individuals, the elderly, and children, to receive medical care. An increase in co-payments could also negatively affect people's health by discouraging them from seeking treatment. For this reason, a reimbursement system that would not raise the actual price should be examined as a means of curbing excessive demand, in addition a co-payment system.

There have been several studies regarding the effects of co-payments on people's use of medical services and their health. For example, Newhouse et al. (1993) ${ }^{1)}$ conducted the RAND Health Insurance Experiment to calculate the price elasticity of a co-payment system. The absolute value was lower than 1.00 for all calculations. In addition, according to a systematic review by Kiil et al. $(2014),{ }^{2)}$ all the reports examined indicated that a $1 \%$ increase in co-payments led to a decline in demand (of less than 1\%) for medical services from individual patients. Thus, although it is inelastic, an increase in co-payments generally lead to a decline in demand for medical services. However, there are also reports indicating that absolutely no effects were seen, or that no effects were seen with respect to health conditions requiring urgent medical attention. It is possible, therefore, that the rate of decline in demand may differ depending on the payment terms and medical condition.

An experiment was conducted in Oregon, United States, to examine the effects of Medicaid, a public medical programme for low-income people in the country, on the demand among people who had been on the programme for two years and its contribution to overall health. The results indicated that the programme did lead to an increase in the use of medical services. In the RAND Health Insurance Experiment, co-payments led to a decline in demand for medical services. In particular, co-payments had a negative impact on the health of low-income people with high-blood pressure or eye problems. However, the introduction of the co-payment system did not otherwise have any adverse impact on the health of the overall population (Keeler et al. 1987). ${ }^{3)}$

On the other hand, a reimbursement system is often proposed alongside the co-payment system as a means of 
discouraging unnecessary or overlapping visits to medical institutions. In France, the current reimbursement system has existed since the 1920s (The social security study group of National Federation of Health Insurance Societies 2014). ${ }^{4}$ In Japan, normally, once the medical institution has the public funds to pay for it, though, but if you are unable to present proof of rights and the individual makes advance payment, it usually takes one to four months to receive reimbursements because of administrative paperwork. In particular, elderly people and people with chronic illnesses or disabilities must wait for a long time because they see various specialists (Nay et al. 2016). ${ }^{5}$

Studies conducted in Japan include Nagamine et al. (2016), ${ }^{6)}$ who examined a system that provides free medical care to children up to sixth grade. The study, which analysed outpatient claim data for 'City A' from 2009 until 2013, indicates that there was no significant increase in the number of children seeking medical care after a reimbursement system was introduced. However, the number did rise significantly after in-kind services began. Iwamoto $(2010)^{7)}$ used nationwide prefectural data to analyse the relationship between payment methods under which direct payment of medical expenses are not required (service in-kind vs reimbursements) and per-person medical expenses for children less than three. The study suggests that public medical expenditure increased (demand for medical care increased) after a reimbursement system was changed to a service in-kind system that provides free medical care. Takaku et al. (2017) ${ }^{8}$ examined a 1971 incident in which nationwide physicians went on strike. At that time, patients were asked to pay all their medical expenses in advance and claim reimbursements later. The study shows that the reimbursement system led to a decline in the use of medical services.

Even so, there are very few studies, if any, in Japan or elsewhere, that quantitatively examined how a reimbursement system may influence the use of medical services. Thus, the present study conducted a conjoint analysis to examine how a co-payment and advance payment may influence people's decision to seek medical care for themselves or for their children.

\section{Methods}

\section{(1) Questionnaire survey}

For this study, an online questionnaire survey was conducted in March 2019, targeting people in Japan to examine how co-payments or advance payments (by patients) may affect people's eagerness to seek medical care This study is cross-sectional study, and the respondents were online participants recruited by the survey company Macromill Inc., based on family structure and household income, described below.

The questionnaire survey was distributed so that it would correspond to the distribution of various types of households shown in the 2015 population census: single-person households, households of married couples, households of married couples with children, and single-parent households with children. A total of 2,600 people were surveyed, including 2,000 from households on welfare and other low-income households that may qualify for welfare. An additional 600 people were chosen from middle-income households that earn between 6 and 12 million yen a year.

Among the total of 2,000 people from households on welfare and low-income households, 458 were chosen from households on welfare and 1,542 from other low-income households, in accordance with a 2016 national survey that shows the percentage of welfare households $(22.9 \%)$ in the number of low-income households below welfare threshold with respect to income only (not taking into account savings). In collecting the votes, we screened Macromill Inc. monitors until the number of those who met the criteria was available. As a result, 320,116 people were screened to ensure that the number, including preliminary votes, was available.

The definition of low-income households in this survey is based on the welfare payments amount obtained through this formula: living expenses $(600,000$ yen $+600,000$ yen $x$ the number of people in the household $)+$ housing expenses $(360,000$ yen $+240,000 \mathrm{x}$ the number of people in the household). Households with annual income similar to, or below, this figure are regarded as low-income households (see the household annual income requirements in Table 1). We do not include category of low-income households if the number of children would be four or more and if the annual household income would be more than 6 million yen. 
Table 1. Online survey participants

\begin{tabular}{|c|c|c|c|}
\hline & Category & $\begin{array}{l}\text { Number of } \\
\text { samples }\end{array}$ & The household annual income requirements \\
\hline \multirow{4}{*}{$\begin{array}{l}\text { Households } \\
\text { on welfare }\end{array}$} & Households of married couples & 102 & \\
\hline & Households of married couples with children & 136 & \\
\hline & Single-parent households with children & 45 & \\
\hline & Single-person households & 175 & \\
\hline \multirow{4}{*}{$\begin{array}{l}\text { Other } \\
\text { low-income } \\
\text { household }\end{array}$} & Households of married couples & 343 & Less than 4 million yen \\
\hline & Households of married couples with children & 457 & $\begin{array}{l}1 \text { child : Less than } 4 \text { million yen } \\
2 \sim 3 \text { children : Less than } 6 \text { million yen } \\
4 \text { or more children : Not surveyed }\end{array}$ \\
\hline & Single-parent households with children & 152 & $\begin{array}{l}1 \sim 2 \text { children : Less than } 4 \text { million yen } \\
3 \text { children : Less than } 6 \text { million yen } \\
4 \text { or more children: Not surveyed }\end{array}$ \\
\hline & Single-person households & 590 & Less than 2 million yen \\
\hline \multirow{4}{*}{$\begin{array}{l}\text { Middle-income } \\
\text { household }\end{array}$} & Households of married couples & 134 & \\
\hline & Households of married couples with children & 178 & \\
\hline & Single-parent households with children & 59 & \\
\hline & Single-person households & 229 & \\
\hline
\end{tabular}

Middle-income households are those with an annual household income ranging from 6 million yen to less than 12 million yen. The number of children was not considered. The distribution of the 600 people from these households is shown in Table 1.

In regard to the settings of location, it is possible to consider that our samples represents the entire Japanese population to some extent because the monitors who responded our survey were from all prefectures in Japan. However, it should be noted that since the survey was conducted online, the number of elderly respondents may be smaller than population.

The following is an overview of the survey questions.

$>$ Household type and household income (for assignment to the appropriate sample group)

$>$ Whether they are on welfare (for assignment to the appropriate sample group)

$>$ Any changes in their eagerness to seek treatment if there is a change in co-payments amount, advance payment amount (targets of reimbursements), and the time it takes to receive reimbursements (based on a conjoint analysis)

$>$ If respondents provided the same answers under all the terms presented (i.e., the physical conditions, copayments amount, advance payment amount, and days needed for reimbursement), they were asked about their true intentions regarding medical care (to check their credibility)

\section{(2) Conjoint analysis}

Conjoint analysis, where the respondents' likes and dislikes about certain options (goods), based on various factors (attributes), are given in the order of preference, simultaneously estimates the effects of the individual attributes and their combinations based on the ranking data.

Consumers, when asked about their preferences regarding certain choices would find it easier to provide the order of their preference than to explain how much they like each of the individual options. The primary focus is to analyse which options are preferred and which attributes have contributed to the selection process (in this study, decisions regarding medical care) based on the ranking data obtained in this manner. 
Table 2. Health condition in conjoint analysis

\begin{tabular}{|c|c|c|}
\hline & Health condition & $\begin{array}{l}\text { Whether medical } \\
\text { exam is needed }\end{array}$ \\
\hline \multirow[t]{4}{*}{ Participants } & $\begin{array}{l}\text { If you discovered that you have high-blood pressure in a health check-up, } \\
\text { would you visit a hospital or clinic under the following terms? }\end{array}$ & Needed \\
\hline & $\begin{array}{l}\text { If you have a fever of } 38^{\circ} \mathrm{C} \text { or higher for two days in a row, would you visit a } \\
\text { hospital or clinic under the following terms? }\end{array}$ & Needed \\
\hline & $\begin{array}{l}\text { If you have a recurrence of lower-back pain, would you visit a hospital or } \\
\text { clinic under the following terms? }\end{array}$ & $\begin{array}{l}\text { Not needed (or the } \\
\text { urgency is low) }\end{array}$ \\
\hline & $\begin{array}{l}\text { In a situation where you cannot fall asleep within an hour, and if this occurs } \\
\text { twice a week, would you visit a hospital or clinic under the following terms? }\end{array}$ & $\begin{array}{l}\text { Not needed (or the } \\
\text { urgency is low) }\end{array}$ \\
\hline \multirow[t]{4}{*}{ Participants' children } & $\begin{array}{l}\text { If your children have rough skin every winter, would you take them to a } \\
\text { hospital or clinic under the following terms? }\end{array}$ & $\begin{array}{l}\text { Not needed (or the } \\
\text { urgency is low) }\end{array}$ \\
\hline & $\begin{array}{l}\text { If your children have a fever of } 38^{\circ} \mathrm{C} \text { or higher for two days in a row, would } \\
\text { you take them to a hospital or clinic under the following terms? }\end{array}$ & Needed \\
\hline & $\begin{array}{l}\text { If your children vomit, but the vomiting later stops (children have no fevers } \\
\text { and have an appetite), would you take them to a hospital or clinic under the } \\
\text { following terms? }\end{array}$ & $\begin{array}{l}\text { Not needed (or the } \\
\text { urgency is low) }\end{array}$ \\
\hline & $\begin{array}{l}\text { If your children are found to have cavities during a school dental exam, would } \\
\text { you take them to a dentist under the following terms? }\end{array}$ & Needed \\
\hline
\end{tabular}

Conjoint analysis, which uses data on individuals' order of preference regarding consumption behaviour and choices, makes it possible to understand how certain goods are evaluated in a market or segment comprising consumers with diverse preferences, rather than using detailed information regarding how particular individuals evaluate certain choices.

In addition, it can quantitatively evaluate items (attributes) that affect people's choices and the weighting of the attributes themselves. Thus, it can estimate the effects of certain goods and consumers' choice behaviour. Moreover, it can also be used when analysing the selection process (Chiba et al. 1997). ${ }^{9}$

The objective of this study is to measure changes in people's eagerness to seek medical care in response to changes in co-payments, advance payments, and the number of days it takes for patients to receive reimbursements. Thus, a conjoint analysis seems to be an ideal method. This study has established three attributes: co-payments, advance payments, and how many days it takes for patients to receive reimbursements. Regarding the level of co-payments and advance payments, rough estimates were made for medical expenses for various ailments based on available data. Considering that co-payments are usually between $10 \%$ and $30 \%$ of the total expenses, the range of fluctuations for both types of payments was set at $10 \%$ of the total expenses. As regards the number of days required for patients to receive reimbursements, the figure was set based on actual data.

Estimated medical expenses for the physical conditions subject to this conjoint analysis are provided below (Table 2). This study used a conditional logistic regression analysis to obtain estimates.

\section{$<$ Total medical expenses $>$}

Expenses for high-blood pressure were set at 16,000 yen per month, and for other conditions they were set at 6,000 yen per session.

For the conjoint analysis, co-payments for high-blood pressure were set at four different levels: 0 yen, 1,600 yen, 3,200 yen, and 4,800 yen (for other conditions, co-payments were 0 yen, 600 yen, 1,200 yen, and 1,800 yen). Advance payments for high-blood pressure were set at 1,600 yen, 3,200 yen, 4,800 yen, and 6,400 yen (for other conditions, the figures were 600 yen, 1,200 yen, 1,800 yen, and 2,400 yen). Days required for reimbursements were set at $0,30,45$, and 90 ). 
However, if the number of days required for reimbursements is 0 , the amount of advance payments is also considered to be 0 . In addition, a question has been created for all participants such that co-payments, advance payments, and the number of days before reimbursement are all zero for reference purposes (the payment terms in card number 0 in Table 3). For this reason, one of the criteria used for the orthogonal table is the overlapping number of days before reimbursement (card number 1 and number 17 in Table 3).

Assignments were also made for patterns 1,2, 3 and 4, in each category of participants (explained by Table 1). In assigning patterns, special attention was paid to ensure that the total number of patterns 1 to 4 was the same when allocating fractions that could not be divided by 4 in each category of participants.

For explaining the payment terms in conjoint analysis, for example, on card number 5 in Table 3, "An individual pays a total of 3,200 yen to the medical institution" and "Subsequently, he/she asks the local government for a reimbursement and receives 1,600 yen 30 days later" are displayed.

People's eagerness to seek medical care was also documented for each physical condition and in accordance with how medical expenses are paid.

The results of the conjoint analysis were examined through a conditional logistic regression analysis because set the probability of a visit for each individual as a common intensity of response regarding the amount and number of days. The clogit command was used in statistics software R 3.1.3 and Stata 11 (Especially in the calculation of marginal effects) by establishing the following two models:

Table 3. Suggested monthly payments in each physical condition

\begin{tabular}{|c|c|c|c|c|c|c|}
\hline & $\begin{array}{l}\text { Card } \\
\text { No. }\end{array}$ & $\begin{array}{l}\text { Co-payments } \\
\quad \text { (yen) }\end{array}$ & $\begin{array}{l}\text { Advance } \\
\text { payments } \\
\text { (yen) }\end{array}$ & $\begin{array}{l}\text { Days required } \\
\text { for } \\
\text { reimbursements } \\
\text { (day) }\end{array}$ & Applied Pattern & $\begin{array}{l}\text { Payment } \\
\text { for } \\
\text { medical } \\
\text { institution } \\
\text { (yen) }\end{array}$ \\
\hline Common & 0 & 0 & 0 & 0 & All Pattern & 0 \\
\hline \multirow{16}{*}{$\begin{array}{l}\text { Regarding } \\
\text { high-blood } \\
\text { pressure }\end{array}$} & 1 & 0 & 1,600 & 90 & 【Pattern1】 & 1,600 \\
\hline & 2 & 0 & 3,200 & 30 & 【Pattern2】 & 3,200 \\
\hline & 3 & 0 & 4,800 & 45 & 【Pattern3】 & 4,800 \\
\hline & 4 & 0 & 6,400 & 90 & 【Pattern4】 & 6,400 \\
\hline & 5 & 1,600 & 1,600 & 30 & 【Pattern4】 & 3,200 \\
\hline & 6 & 1,600 & 0 & 0 & 【Pattern3】 & 1,600 \\
\hline & 7 & 1,600 & 4,800 & 90 & 【Pattern2】 & 6,400 \\
\hline & 8 & 1,600 & 6,400 & 45 & 【Pattern1】 & 8,000 \\
\hline & 9 & 3,200 & 1,600 & 45 & 【Pattern2】 & 4,800 \\
\hline & 10 & 3,200 & 3,200 & 90 & 【Pattern1】 & 6,400 \\
\hline & 11 & 3,200 & 0 & 0 & 【Pattern4】 & 3,200 \\
\hline & 12 & 3,200 & 6,400 & 30 & 【Pattern3】 & 9,600 \\
\hline & 13 & 4,800 & 1,600 & 90 & 【Pattern3】 & 6,400 \\
\hline & 14 & 4,800 & 3,200 & 45 & 【Pattern4】 & 8,000 \\
\hline & 15 & 4,800 & 4,800 & 30 & 【Pattern1】 & 9,600 \\
\hline & 16 & 4,800 & 0 & 0 & 【Pattern2】 & 4,800 \\
\hline
\end{tabular}




\begin{tabular}{|c|c|c|c|c|c|c|}
\hline & $\begin{array}{l}\text { Card } \\
\text { No. }\end{array}$ & $\begin{array}{l}\text { Co-payments } \\
\quad \text { (yen) }\end{array}$ & $\begin{array}{l}\text { Advance } \\
\text { payments } \\
\text { (yen) }\end{array}$ & $\begin{array}{l}\text { Days required } \\
\text { for } \\
\text { reimbursements } \\
\text { (day) }\end{array}$ & Applied Pattern & $\begin{array}{l}\text { Payment } \\
\text { for } \\
\text { medical } \\
\text { institution } \\
\text { (yen) }\end{array}$ \\
\hline \multirow{16}{*}{$\begin{array}{l}\text { Regarding } \\
\text { conditions } \\
\text { other than } \\
\text { high-blood } \\
\text { pressure }\end{array}$} & 17 & 0 & 600 & 90 & 【Pattern1】 & 600 \\
\hline & 18 & 0 & 1,200 & 30 & 【Pattern2】 & 1,200 \\
\hline & 19 & 0 & 1,800 & 45 & 【Pattern3】 & 1,800 \\
\hline & 20 & 0 & 2,400 & 90 & 【Pattern4】 & 2,400 \\
\hline & 21 & 600 & 600 & 30 & 【Pattern4】 & 1,200 \\
\hline & 22 & 600 & 0 & 0 & 【Pattern3】 & 600 \\
\hline & 23 & 600 & 1,800 & 90 & 【Pattern2】 & 2,400 \\
\hline & 24 & 600 & 2,400 & 45 & 【Pattern1】 & 3,000 \\
\hline & 25 & 1,200 & 600 & 45 & 【Pattern2】 & 1,800 \\
\hline & 26 & 1,200 & 1,200 & 90 & 【Pattern1】 & 2,400 \\
\hline & 27 & 1,200 & 0 & 0 & 【Pattern4】 & 1,200 \\
\hline & 28 & 1,200 & 2,400 & 30 & 【Pattern3】 & 3,600 \\
\hline & 29 & 1,800 & 600 & 90 & 【Pattern3】 & 2,400 \\
\hline & 30 & 1,800 & 1,200 & 45 & 【Pattern4】 & 3,000 \\
\hline & 31 & 1,800 & 1,800 & 30 & 【Pattern1】 & 3,600 \\
\hline & 32 & 1,800 & 0 & 0 & 【Pattern2】 & 1,800 \\
\hline
\end{tabular}

\section{$<$ Model (1) $>$}

$\bigcirc$ 'Decision to seek medical care' (Note 2) as the dependent variable

0 'Co-payment amount' and 'existence of advance payments (= whether patients must wait more than one day to receive reimbursements)' as explanatory variables

$$
p_{i}\left(x_{c}, x_{a e}\right)=\frac{1}{1+\exp \left\{-\left(b_{c} x_{c}+b_{a e} x_{a e}+u_{i}\right)\right\}}
$$

$p \cdots$ Probability of seeking medical care

$x_{c} \cdots$ Co-payment amount

$x_{a e} \cdots$ Existence of advance payment (Exist $=1$, Not exist $=0$ )

$b_{c}, b_{a e} \cdots$ Coefficients of each variable

$u_{i} \cdots$ Random intercept by individual

$<$ Model (2)>

- 'Decision to seek medical care' as the dependent variable

○ 'Co-payment amount', 'advance payments amount', and 'the number of days before reimbursements' as explanatory variables

$$
p_{i}\left(x_{c}, x_{a}, x_{d}\right)=\frac{1}{1+\exp \left\{-\left(b_{c} x_{c}+b_{a} x_{a}+b_{d} x_{d}+u_{i}\right)\right\}}
$$

$p \cdots$ Probability of seeking medical care 
$x_{c} \cdots$ Co-payment amount (unit: 1,000 yen)

$x_{a} \cdots$ Advance payments amount (unit: 1,000 yen)

$x_{d} \cdots$ The number of days before reimbursements (unit: 10 days)

$b_{c}, b_{a}, b_{d} \cdots$ Coefficients of each variable

$u_{i} \cdots$ Random intercept by individual

It is theoretically possible that, when advance payments and reimbursement days change from 0 to another value, the utility level (here, the factors that make people decide to seek medical care or have their children receive medical care) significantly declines, and that the utility level also declines slightly with an increase in advance payments and reimbursement days. Therefore, observations were made for any change in people's decisions depending on whether or not they had to make advance payments, as well as any change in accordance with how much they had to pay as advance payments and how long they had to wait for reimbursements.

It is possible that people who responded that they would seek medical care for themselves or for their children for all medical conditions, and those who responded that they would not seek medical care for themselves or for their children for any medical conditions, may have chosen their answers mechanically and may not have been truthful. These people were excluded from the conditional logistic regression analysis, regardless of their intentions. Thus, they were not removed from the sample at the outset.

After calculating the coefficients of the model, we calculated the marginal effects (dy/dx) and assessed the change in the probability of seeing a doctor from the change per unit of the variable.

For those cases where the coefficient on the advance payment is significant, the calculated model coefficients $R_{a c}$ were used to evaluate the co-payment of 1,000 yen for the advance payment.

$$
R_{a c}=\frac{b_{a}}{b_{c}} \times 1000
$$

\section{(3) Ethical considerations}

The online survey was reviewed by the institutional review board of the Graduate School of Business Administration, Keio University, which approved this research under the title 'Research Regarding Changes in People's Eagerness to Seek Treatment in Accordance with Co-Payments and Advance Payments'.

Macromill was hired to conduct the survey. The company received a 'privacy mark' from JIPDEC, an organization established to promote personal information protection. Thus, Macromill can be relied on to protect the private information of survey participants. The data received from the company had already been processed in such a way that individual participants could not be identified. Individual participants cannot be traced based on the analysis results either.

\section{Results}

\section{(1) Characteristics of participants}

The following is the information of age regarding household members by income level (Table 4).

Among households on welfare and low-income households, the distribution of people in their 30s through 60 s was skewed towards those in their 40s and 50s. Among middle-income households, the percentage of younger people and elderly people tended to be low (Table 4).

The number of respondents by gender was 251 males and 207 females in households on welfare, 626 males and 916 females in other low-income households, and 322 males and 278 females in middle-income households. Many participants from low-income households were women, whereas many participants from households on welfare and middle-income households were men. 
Table 4. Distribution of people by household income and age

\begin{tabular}{|c|c|c|c|}
\hline & $\begin{array}{l}\text { Households on } \\
\text { welfare }\end{array}$ & $\begin{array}{c}\text { Other low-income } \\
\text { household }\end{array}$ & $\begin{array}{l}\text { Middle-income } \\
\text { household }\end{array}$ \\
\hline \multirow[t]{2}{*}{$20 \mathrm{~s}$} & 48 & 164 & 46 \\
\hline & $10.5 \%$ & $10.6 \%$ & $7.7 \%$ \\
\hline \multirow[t]{2}{*}{$30 \mathrm{~s}$} & 95 & 425 & 132 \\
\hline & $20.7 \%$ & $27.6 \%$ & $22.0 \%$ \\
\hline \multirow[t]{2}{*}{$40 \mathrm{~s}$} & 146 & 421 & 237 \\
\hline & $31.9 \%$ & $27.3 \%$ & $39.5 \%$ \\
\hline \multirow[t]{2}{*}{$50 \mathrm{~s}$} & 105 & 263 & 160 \\
\hline & $22.9 \%$ & $17.1 \%$ & $26.7 \%$ \\
\hline \multirow[t]{2}{*}{ Over $60 \mathrm{~s}$} & 64 & 269 & 25 \\
\hline & $14.0 \%$ & $17.4 \%$ & $4.2 \%$ \\
\hline Total & 458 & 1,542 & 600 \\
\hline
\end{tabular}

(2) Percentage of people eager to seek medical care by income level

Regarding the questions used in the conjoint analysis, the percentage of people who said that they would seek medical care for themselves or for their children in response to the presented patterns under suggested payment terms and medical condition were as follows (Fig. 1, Fig. 2):

For conditions requiring medical care, approximately $80 \%$ of the respondents said that they would seek treatment for themselves (for high-blood pressure and fevers) (Fig. 1) and approximately $90 \%$ said that they would seek treatment for their children (for fevers and cavities) (Fig. 2) if they did not have to make any payments. If co-payments increased, the percentage of people who would seek medical care for themselves declines relatively sharply among those in low-income households, and the percentage of people who would seek medical care for their children declines relatively sharply among households on welfare.

For conditions that may not necessarily require immediate treatment, which include lower-back pain and difficulty sleeping for adults (Fig. 1) and rough skin and vomiting for children (Fig. 2), a lower percentage of people overall responded that they would seek treatment for themselves or for their children. However, a relatively high percentage of people on welfare, and to a lesser extent, lower-income people, said that they would seek treatment for their children for such conditions.

\section{(3) Conditional logistic regression analysis}

Participants included in the conditional logistic regression analysis were limited to those who would change their mind regarding whether to seek treatment for themselves or for their children depending on the suggested payment terms and medical condition. The results apply only to those who responded that they would seek treatment depending on the suggested terms (Table 5, Table 6).

The results of the analysis of Model (1) show that the co-payment coefficient was 5\%, a significant figure, for all cases, except for cavities for children in middle-income households. The significance of the coefficient for advance payments was as follows (Table 7):

Approximately $30-40 \%$ of the respondents (Table 5, Table 6) from all household groups said that they would change their mind about seeking medical care for any medical condition that they themselves might experience, and any rough skin and one-time vomiting that their children might have, depending on the terms of co-payments and advance payment. Meanwhile, regarding children's fevers and cavities, only 13-28\% of the participants said that they would change their mind about medical care depending on the payment terms (Table 6). There was a rough correspondence between co-payments and people's decisions regarding medical care, but almost no 

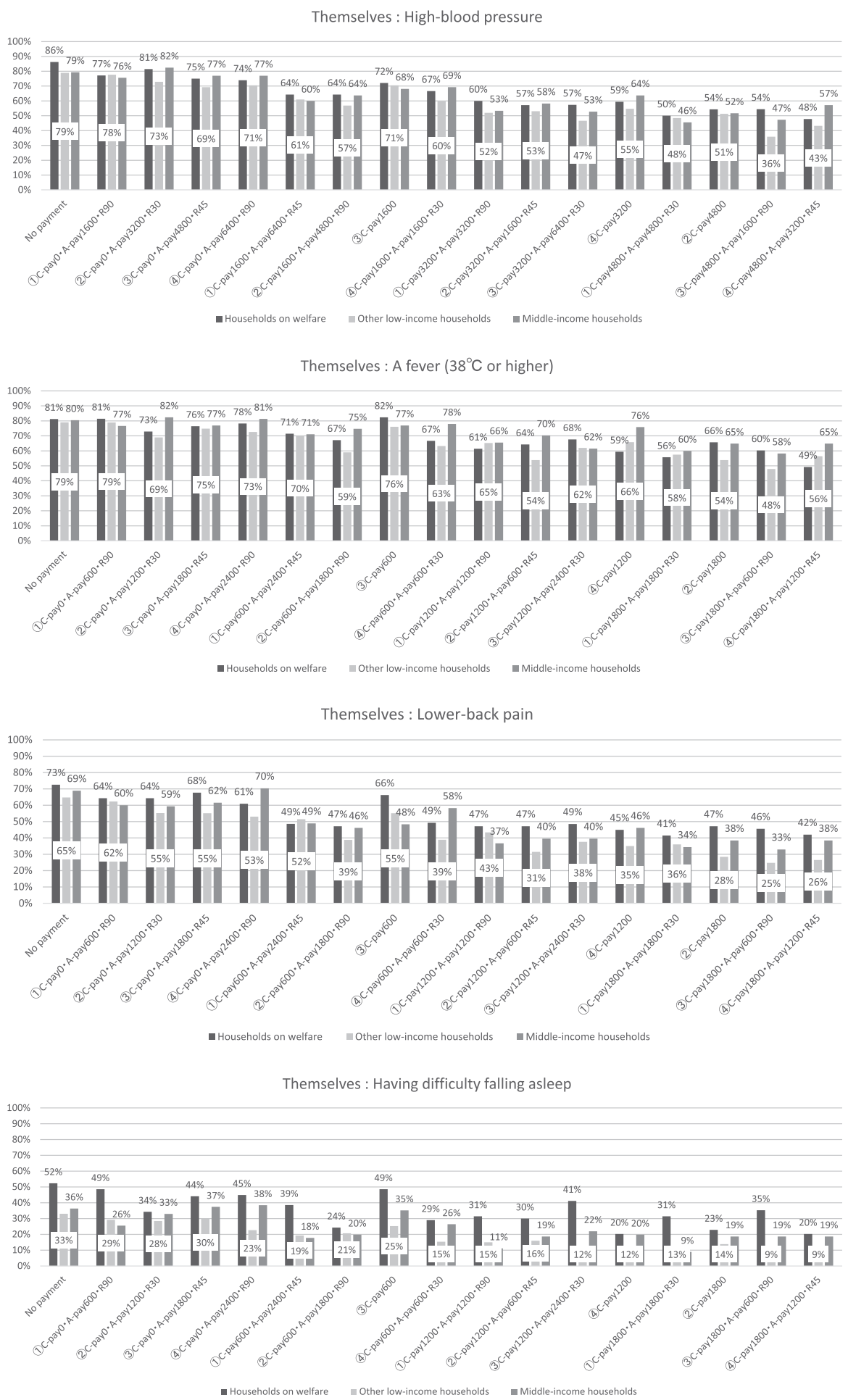

Figure 1. Percentages of those who said that they would seek medical care for their own health conditions ※ The numbers in circles on the horizontal axis represent various patterns. Except for 'no co-payment/advance payments' to which everyone is subject, the numbers correspond to patterns of questions in conjoint analysis.

※ C-pay: Co-payments (unit: yen), A-pay: Advance payments (unit: yen), R: Days required for reimbursements (unit: day) 

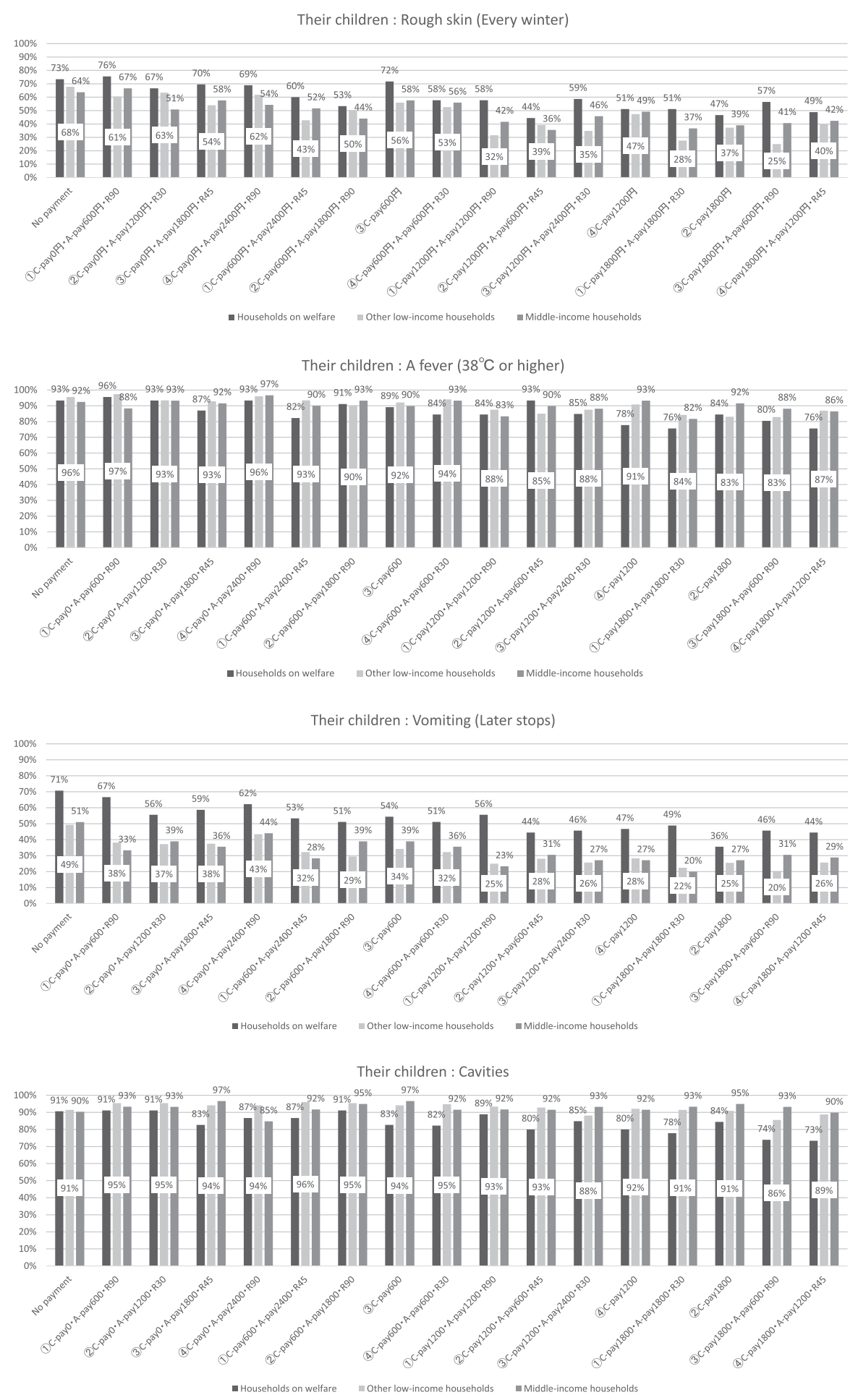

Figure 2. Percentages of those who said that they would seek treatment for their children's health conditions

※ The numbers in circles on the horizontal axis represent various patterns. Except for 'no co-payment/advance payments' to which everyone is subject, the numbers correspond to patterns of questions in conjoint analysis.

※ C-pay: Co-payments (unit: yen), A-pay: Advance payments (unit: yen), R: Days required for reimbursements (unit: day) 
Table 5. Counts and percentages of response patterns for each question regarding participants' own health conditions

\begin{tabular}{|c|c|c|c|c|}
\hline & & $\begin{array}{c}\text { Households on } \\
\text { welfare }\end{array}$ & $\begin{array}{c}\text { Other } \\
\text { low-income } \\
\text { household }\end{array}$ & $\begin{array}{l}\text { Middle-income } \\
\text { household }\end{array}$ \\
\hline \multirow{6}{*}{$\begin{array}{l}\text { High-blood } \\
\text { pressure }\end{array}$} & \multirow{2}{*}{$\begin{array}{l}\text { Not seek } \\
\text { treatment }\end{array}$} & 27 & 154 & 61 \\
\hline & & $9.7 \%$ & $16.5 \%$ & $16.8 \%$ \\
\hline & \multirow{2}{*}{$\begin{array}{l}\text { Depending on } \\
\text { payment terms }\end{array}$} & 122 & 404 & 130 \\
\hline & & $44.0 \%$ & $43.3 \%$ & $35.8 \%$ \\
\hline & \multirow[t]{2}{*}{ Seek treatment } & 128 & 375 & 172 \\
\hline & & $46.2 \%$ & $40.2 \%$ & $47.4 \%$ \\
\hline \multirow[t]{6}{*}{ A fever } & \multirow{2}{*}{$\begin{array}{l}\text { Not seek } \\
\text { treatment }\end{array}$} & 33 & 168 & 55 \\
\hline & & $11.9 \%$ & $18.0 \%$ & $15.2 \%$ \\
\hline & \multirow{2}{*}{$\begin{array}{l}\text { Depending on } \\
\text { payment terms }\end{array}$} & 106 & 301 & 99 \\
\hline & & $38.3 \%$ & $32.3 \%$ & $27.3 \%$ \\
\hline & \multirow[t]{2}{*}{ Seek treatment } & 138 & 464 & 209 \\
\hline & & $49.8 \%$ & $49.7 \%$ & $57.6 \%$ \\
\hline \multirow{6}{*}{$\begin{array}{c}\text { Lower-back } \\
\text { pain }\end{array}$} & \multirow{2}{*}{$\begin{array}{l}\text { Not seek } \\
\text { treatment }\end{array}$} & 61 & 305 & 104 \\
\hline & & $22.0 \%$ & $32.7 \%$ & $28.7 \%$ \\
\hline & \multirow{2}{*}{$\begin{array}{l}\text { Depending on } \\
\text { payment terms }\end{array}$} & 113 & 385 & 141 \\
\hline & & $40.8 \%$ & $41.3 \%$ & $38.8 \%$ \\
\hline & \multirow[t]{2}{*}{ Seek treatment } & 103 & 243 & 118 \\
\hline & & $37.2 \%$ & $26.0 \%$ & $32.5 \%$ \\
\hline \multirow{7}{*}{$\begin{array}{c}\text { Having } \\
\text { difficulty } \\
\text { falling asleep }\end{array}$} & \multirow{2}{*}{$\begin{array}{l}\text { Not seek } \\
\text { treatment }\end{array}$} & 122 & 597 & 219 \\
\hline & & $44.0 \%$ & $64.0 \%$ & $60.3 \%$ \\
\hline & \multirow{2}{*}{$\begin{array}{l}\text { Depending on } \\
\text { payment terms }\end{array}$} & 91 & 245 & 96 \\
\hline & & $32.9 \%$ & $26.3 \%$ & $26.4 \%$ \\
\hline & \multirow[t]{2}{*}{ Seek treatment } & 64 & 91 & 48 \\
\hline & & $23.1 \%$ & $9.8 \%$ & $13.2 \%$ \\
\hline & Total & 277 & 933 & 363 \\
\hline
\end{tabular}


Table 6. Counts and percentages of response patterns for each question regarding health conditions for participants' children

\begin{tabular}{|c|c|c|c|c|}
\hline & & $\begin{array}{c}\text { Households on } \\
\text { welfare }\end{array}$ & $\begin{array}{c}\text { Other } \\
\text { low-income } \\
\text { household }\end{array}$ & $\begin{array}{l}\text { Middle-income } \\
\text { household }\end{array}$ \\
\hline \multirow[t]{6}{*}{ Rough skin } & \multirow{2}{*}{$\begin{array}{l}\text { Not seek } \\
\text { treatment }\end{array}$} & 39 & 170 & 73 \\
\hline & & $21.5 \%$ & $27.9 \%$ & $30.8 \%$ \\
\hline & \multirow{2}{*}{$\begin{array}{l}\text { Depending on } \\
\text { payment terms }\end{array}$} & 58 & 266 & 81 \\
\hline & & $32.0 \%$ & $43.7 \%$ & $34.2 \%$ \\
\hline & \multirow[t]{2}{*}{ Seek treatment } & 84 & 173 & 83 \\
\hline & & $46.4 \%$ & $28.4 \%$ & $35.0 \%$ \\
\hline \multirow{6}{*}{ A fever } & \multirow{2}{*}{$\begin{array}{l}\text { Not seek } \\
\text { treatment }\end{array}$} & 5 & 11 & 11 \\
\hline & & $2.8 \%$ & $1.8 \%$ & $4.6 \%$ \\
\hline & \multirow{2}{*}{$\begin{array}{l}\text { Depending on } \\
\text { payment terms }\end{array}$} & 46 & 109 & 31 \\
\hline & & $25.4 \%$ & $17.9 \%$ & $13.1 \%$ \\
\hline & \multirow[t]{2}{*}{ Seek treatment } & 130 & 489 & 195 \\
\hline & & $71.8 \%$ & $80.3 \%$ & $82.3 \%$ \\
\hline \multirow[t]{6}{*}{ Vomiting } & \multirow{2}{*}{$\begin{array}{l}\text { Not seek } \\
\text { treatment }\end{array}$} & 49 & 298 & 113 \\
\hline & & $27.1 \%$ & $48.9 \%$ & $47.7 \%$ \\
\hline & \multirow{2}{*}{$\begin{array}{l}\text { Depending on } \\
\text { payment terms }\end{array}$} & 58 & 180 & 64 \\
\hline & & $32.0 \%$ & $29.6 \%$ & $27.0 \%$ \\
\hline & \multirow{2}{*}{ Seek treatment } & 74 & 131 & 60 \\
\hline & & $40.9 \%$ & $21.5 \%$ & $25.3 \%$ \\
\hline \multirow[t]{7}{*}{ Cavities } & \multirow{2}{*}{$\begin{array}{l}\text { Not seek } \\
\text { treatment }\end{array}$} & 5 & 9 & 7 \\
\hline & & $2.8 \%$ & $1.5 \%$ & $3.0 \%$ \\
\hline & \multirow{2}{*}{$\begin{array}{l}\text { Depending on } \\
\text { payment terms }\end{array}$} & 51 & 101 & 31 \\
\hline & & $28.2 \%$ & $16.6 \%$ & $13.1 \%$ \\
\hline & \multirow[t]{2}{*}{ Seek treatment } & 125 & 499 & 199 \\
\hline & & $69.1 \%$ & $81.9 \%$ & $84.0 \%$ \\
\hline & Total & 181 & 609 & 237 \\
\hline
\end{tabular}


Table 7. Significance of the coefficients of advance payments when the existence or nonexistence of payments is included in the model

\begin{tabular}{|l|l|l|l|}
\hline & \multicolumn{1}{|c|}{ Households on welfare } & \multicolumn{1}{|c|}{$\begin{array}{c}\text { Other low-income } \\
\text { household }\end{array}$} & \multicolumn{1}{c|}{$\begin{array}{c}\text { Middle-income } \\
\text { household }\end{array}$} \\
\hline $\begin{array}{l}\text { Themselves: } \\
\text { High-blood pressure }\end{array}$ & $* * *$ & $* * *$ & $* *$ \\
\hline Themselves: A fever & $* * *$ & $* * *$ & $*$ \\
\hline Themselves: Lower-back pain & $* * *$ & $* * *$ & $* *$ \\
\hline $\begin{array}{l}\text { Themselves: Having difficulty } \\
\text { falling asleep }\end{array}$ & $* * *$ & $* * *$ & $* *$ \\
\hline Their children: Rough skin & $*$ & $* * *$ & $* * *$ \\
\hline Their children: A fever & n.s. & n.s. & n.s. \\
\hline Their children: Vomiting & $* *$ & $* * *$ & $* * *$ \\
\hline Their children: Cavities & n.s. & $*$ & n.s. \\
\hline
\end{tabular}

$* * *: \mathrm{p}<0.001, \quad * *: \mathrm{p}<0.01, *: \mathrm{p}<0.05$, n.s. : Not-significant

relationship was observed between advance payments and medical care decisions.

Data regarding people's eagerness to seek medical care for medical conditions that they or their children might experience were examined by a conditional logistic regression analysis at Model (2). The coefficients and the marginal effects for each explanatory variable were as follows (Table 8): The people examined were those who would change their decisions depending on the suggested payment terms. Thus, the counts of these people have been listed in Table 8 .

Advance payments would discourage people from seeking medical care at a strength $0.110-0.270$ of the same amounts of co-payments (by the calculated model coefficients $R_{a c}$ ). For example, 1,000 yen in advance payments would be equivalent to 131 yen in co-payments in terms of the effects of discouraging low-income people from seeking medical care for high-blood pressure (Table 9).

People in low-income households would generally refrain from seeking treatment for their own medical conditions if advance payments were required. People from households on welfare and those from middle-income households would refrain from seeking medical care for various combinations of medical conditions (Table 9).

As regards medical conditions for children, people would not refrain from seeking medical care for conditions for which care is generally recommended. However, some people would avoid medical care for other conditions (Table 9).

\section{Discussion}

\section{(1) For result of the research}

The relationship between an increase in co-payments and people's reluctance to seek medical care is clearly seen regardless of the medical condition or household income, although middle-income households appear to be unaffected when it comes to children's cavities. Thus, people's sensitivity to prices, as seen in other studies, has been observed to a certain extent. On the other hand, the relationship between advance payments as a continuous value and people's reluctance to seek medical care has been observed in some cases but not in others, depending 
Table 8. Results of analysis regarding respondents' eagerness to seek medical care for their own health conditions, and to send medical care for their children's health conditions

\begin{tabular}{|c|c|c|c|c|c|c|c|}
\hline \multirow{2}{*}{\multicolumn{2}{|c|}{$\begin{array}{l}\text { 【For their own health } \\
\text { conditions】 }\end{array}$}} & \multicolumn{2}{|c|}{$\begin{array}{c}\text { Households on } \\
\text { welfare } \\
n=1,385 \text { [277 inds] }\end{array}$} & \multicolumn{2}{|c|}{$\begin{array}{c}\text { Other low-income } \\
\text { households } \\
n=4,665 \text { [933 inds] }\end{array}$} & \multicolumn{2}{|c|}{$\begin{array}{c}\begin{array}{c}\text { Middle-income } \\
\text { households }\end{array} \\
n=1,815 \text { [365 inds }]\end{array}$} \\
\hline & & $\begin{array}{l}\text { Coef. } \\
d y / d x\end{array}$ & (SE) & $\begin{array}{l}\text { Coef. } \\
d y / d x\end{array}$ & (SE) & $\begin{array}{l}\text { Coef. } \\
d y / d x\end{array}$ & (SE) \\
\hline \multirow[t]{4}{*}{$\begin{array}{l}\text { High-blood } \\
\text { pressure }\end{array}$} & C-pay & $\begin{array}{l}-0.806 \\
-0.097\end{array}$ & $(0.076)^{* * * *}$ & $\begin{array}{l}-0.834 \\
-0.100\end{array}$ & $(0.042) * * *$ & $\begin{array}{l}-1.058 \\
-0.121\end{array}$ & $(0.093) * * *$ \\
\hline & A-pay & $\begin{array}{l}-0.152 \\
-0.018\end{array}$ & $(0.060)^{*}$ & $\begin{array}{l}-0.109 \\
-0.013\end{array}$ & $(0.030) * * *$ & $\begin{array}{l}-0.101 \\
-0.012\end{array}$ & $(0.062)$ \\
\hline & $\mathrm{R}$ & $\begin{array}{l}-0.061 \\
-0.007 \\
\end{array}$ & $(0.041)$ & $\begin{array}{l}-0.088 \\
-0.011 \\
\end{array}$ & $(0.022)^{* * *}$ & $\begin{array}{l}-0.063 \\
-0.007 \\
\end{array}$ & $(0.044)$ \\
\hline & $\begin{array}{l}n \\
\text { LL/AIC }\end{array}$ & \multicolumn{2}{|c|}{$\begin{array}{c}610 \text { [122 inds] } \\
-132.46 / 270.91\end{array}$} & \multicolumn{2}{|c|}{$\begin{array}{c}2020 \text { [404 inds] } \\
-421.18 \text { / } 848.35\end{array}$} & \multicolumn{2}{|c|}{$\begin{array}{c}650 \text { [130 inds] } \\
-108.16 / 222.32\end{array}$} \\
\hline \multirow{4}{*}{$\begin{array}{l}\text { A fever } \\
\left(38^{\circ} \mathrm{C} \text { or }\right. \\
\text { higher })\end{array}$} & C-pay & $\begin{array}{l}-1.512 \\
-0.233\end{array}$ & $(0.166)^{* * *}$ & $\begin{array}{l}-2.031 \\
-0.256\end{array}$ & $(0.123) * * *$ & $\begin{array}{l}-1.813 \\
-0.262\end{array}$ & $(0.191)^{* * *}$ \\
\hline & A-pay & $\begin{array}{l}-0.182 \\
-0.028\end{array}$ & $(0.146)$ & $\begin{array}{l}-0.249 \\
-0.031\end{array}$ & $(0.087)^{* *}$ & $\begin{array}{l}-0.303 \\
-0.044\end{array}$ & $(0.147)^{*}$ \\
\hline & $\mathrm{R}$ & $\begin{array}{l}-0.053 \\
-0.008 \\
\end{array}$ & $(0.038)$ & $\begin{array}{l}-0.092 \\
-0.012 \\
\end{array}$ & $(0.023) * * *$ & $\begin{array}{l}-0.016 \\
-0.002 \\
\end{array}$ & $(0.037)$ \\
\hline & $\begin{array}{l}n \\
\text { LL/AIC }\end{array}$ & \multicolumn{2}{|c|}{$\begin{array}{c}530 \text { [106inds] } \\
-147.76 / 301.52\end{array}$} & \multicolumn{2}{|c|}{$\begin{array}{c}1505 \text { [301inds] } \\
-326.36 \text { / } 658.72\end{array}$} & \multicolumn{2}{|c|}{$\begin{array}{l}495 \text { [99inds] } \\
\mathrm{AIC}=251.32\end{array}$} \\
\hline \multirow[t]{4}{*}{$\begin{array}{l}\text { Lower-back } \\
\text { pain }\end{array}$} & C-pay & $\begin{array}{l}-1.756 \\
-0.234\end{array}$ & $(0.180)^{* * * *}$ & $\begin{array}{l}-2.828 \\
-0.305\end{array}$ & $(0.150)^{* * *}$ & $\begin{array}{l}-2.606 \\
-0.324\end{array}$ & $(0.215)^{* * * *}$ \\
\hline & A-pay & $\begin{array}{l}-0.415 \\
-0.055\end{array}$ & $(0.151)^{* *}$ & $\begin{array}{l}-0.311 \\
-0.033\end{array}$ & $(0.095)^{* *}$ & $\begin{array}{l}-0.154 \\
-0.019\end{array}$ & $(0.143)$ \\
\hline & $\mathrm{R}$ & $\begin{array}{l}-0.045 \\
-0.006 \\
\end{array}$ & (0.038) & $\begin{array}{l}-0.099 \\
-0.011 \\
\end{array}$ & $(0.025)^{* * * *}$ & $\begin{array}{l}-0.056 \\
-0.007 \\
\end{array}$ & (0.038) \\
\hline & $\begin{array}{l}n \\
\text { LL/AIC }\end{array}$ & \multicolumn{2}{|c|}{$\begin{array}{c}565 \text { [113inds] } \\
-139.12 / 284.24 \\
\end{array}$} & \multicolumn{2}{|c|}{$\begin{array}{c}1925 \text { [385inds] } \\
-318.62 / 643.23\end{array}$} & \multicolumn{2}{|c|}{$\begin{array}{c}705 \text { [141inds] } \\
-132.52 / 271.04 \\
\end{array}$} \\
\hline \multirow{4}{*}{$\begin{array}{l}\text { Having } \\
\text { difficulty } \\
\text { falling asleep }\end{array}$} & C-pay & $\begin{array}{l}-1.897 \\
-0.249\end{array}$ & $(0.216)^{* * *}$ & $\begin{array}{l}-2.760 \\
-0.313\end{array}$ & $(0.185)^{* * * *}$ & $\begin{array}{l}-2.445 \\
-0.308\end{array}$ & $(0.252)^{* * * *}$ \\
\hline & A-pay & $\begin{array}{l}-0.190 \\
-0.025\end{array}$ & $(0.166)$ & $\begin{array}{l}-0.351 \\
-0.040\end{array}$ & $(0.122)^{* * *}$ & $\begin{array}{l}-0.329 \\
-0.041\end{array}$ & $(0.166)^{*}$ \\
\hline & $\mathrm{R}$ & $\begin{array}{l}-0.090 \\
-0.012 \\
\end{array}$ & $(0.043)^{*}$ & $\begin{array}{l}-0.059 \\
-0.007 \\
\end{array}$ & $(0.033)$ & $\begin{array}{l}-0.022 \\
-0.003 \\
\end{array}$ & $(0.042)$ \\
\hline & $\begin{array}{l}n ' \\
\text { LL/AIC }\end{array}$ & \multicolumn{2}{|c|}{$\begin{array}{c}455 \text { [91inds] } \\
-110.76 / 227.53\end{array}$} & \multicolumn{2}{|c|}{$\begin{array}{c}1225 \text { [245inds] } \\
-214.01 / 434.03 \\
\end{array}$} & \multicolumn{2}{|c|}{$\begin{array}{c}480 \text { [96inds] } \\
-96.71 / 199.42 \\
\end{array}$} \\
\hline
\end{tabular}




\begin{tabular}{|c|c|c|c|c|c|c|c|}
\hline \multirow{2}{*}{\multicolumn{2}{|c|}{$\begin{array}{l}\text { 【For their children's health } \\
\text { conditions】 }\end{array}$}} & \multicolumn{2}{|c|}{$\begin{array}{c}\begin{array}{c}\text { Households on } \\
\text { welfare }\end{array} \\
n=905 \text { (181 people) }\end{array}$} & \multicolumn{2}{|c|}{$\begin{array}{c}\text { Other low-income } \\
\text { household } \\
n=3,045 \text { (609 people) }\end{array}$} & \multicolumn{2}{|c|}{$\begin{array}{c}\begin{array}{c}\text { Middle-income } \\
\text { household }\end{array} \\
n=1,185 \text { (237 people) }\end{array}$} \\
\hline & & $\begin{array}{l}\text { Coef. } \\
d y / d x\end{array}$ & (SE) & $\begin{array}{l}\text { Coef. } \\
d y / d x\end{array}$ & (SE) & $\begin{array}{l}\text { Coef. } \\
d y / d x\end{array}$ & (SE) \\
\hline \multirow{4}{*}{$\begin{array}{l}\text { Rough skin } \\
\text { (Every } \\
\text { winter) }\end{array}$} & C-pay & $\begin{array}{l}-2.093 \\
-0.278\end{array}$ & $(0.284) * * *$ & $\begin{array}{l}-2.541 \\
-0.284\end{array}$ & $(0.161) * * *$ & $\begin{array}{l}-1.826 \\
-0.235\end{array}$ & $(0.221)^{* * * *}$ \\
\hline & A-pay & $\begin{array}{l}-0.401 \\
-0.053\end{array}$ & $(0.206)$ & $\begin{array}{l}-0.331 \\
-0.037\end{array}$ & $(0.105)^{* *}$ & $\begin{array}{l}-0.436 \\
-0.056\end{array}$ & $(0.174)^{*}$ \\
\hline & $\mathrm{R}$ & $\begin{array}{l}-0.005 \\
-0.001\end{array}$ & $(0.051)$ & $\begin{array}{l}-0.090 \\
-0.010\end{array}$ & $(0.029)^{* *}$ & $\begin{array}{l}-0.052 \\
-0.007\end{array}$ & $(0.046)$ \\
\hline & $\begin{array}{l}n \\
\mathrm{LL} / \mathrm{AIC}\end{array}$ & \multicolumn{2}{|c|}{$\begin{array}{c}290 \text { [58inds] } \\
-66.86 / 139.72 \\
\end{array}$} & \multicolumn{2}{|c|}{$\begin{array}{c}1330 \text { [266inds] } \\
-244.06 / 494.12 \\
\end{array}$} & \multicolumn{2}{|c|}{$\begin{array}{c}405 \text { [81people] } \\
-98.48 / 202.97 \\
\end{array}$} \\
\hline \multirow{4}{*}{$\begin{array}{l}\text { A fever } \\
\left(38^{\circ} \mathrm{C} \text { or }\right. \\
\text { higher })\end{array}$} & C-pay & $\begin{array}{l}-1.430 \\
-0.256\end{array}$ & $(0.253)^{* * *}$ & $\begin{array}{l}-1.601 \\
-0.264\end{array}$ & $(0.164)^{* * *}$ & $\begin{array}{l}-1.028 \\
-0.211\end{array}$ & $(0.261)^{* * * *}$ \\
\hline & A-pay & $\begin{array}{l}-0.283 \\
-0.051\end{array}$ & $(0.198)$ & $\begin{array}{l}-0.058 \\
-0.010\end{array}$ & $(0.138)$ & $\begin{array}{l}0.024 \\
0.005\end{array}$ & $(0.239)$ \\
\hline & $\mathrm{R}$ & $\begin{array}{l}0.069 \\
0.012 \\
\end{array}$ & $(0.052)$ & $\begin{array}{l}-0.022 \\
-0.004 \\
\end{array}$ & $(0.035)$ & $\begin{array}{l}0.003 \\
0.001 \\
\end{array}$ & $(0.064)$ \\
\hline & $\begin{array}{l}n \\
\text { LL/AIC }\end{array}$ & \multicolumn{2}{|c|}{$\begin{array}{c}230 \text { [46inds] } \\
-62.76 / 131.53 \\
\end{array}$} & \multicolumn{2}{|c|}{$\begin{array}{c}545 \text { [109inds] } \\
-150.73 / 307.46 \\
\end{array}$} & \multicolumn{2}{|c|}{$\begin{array}{c}155 \text { [31inds] } \\
-51.37 / 108.74 \\
\end{array}$} \\
\hline \multirow[t]{4}{*}{$\begin{array}{l}\text { Vomiting } \\
\text { (Later stops) }\end{array}$} & C-pay & $\begin{array}{l}-2.413 \\
-0.300\end{array}$ & $(0.332)^{* * *}$ & $\begin{array}{l}-2.810 \\
-0.298\end{array}$ & $(0.228)^{* * *}$ & $\begin{array}{l}-3.698 \\
-0.341\end{array}$ & $(0.557)^{* * *}$ \\
\hline & A-pay & $\begin{array}{l}-0.651 \\
-0.081\end{array}$ & $(0.239)^{* *}$ & $\begin{array}{l}-0.227 \\
-0.024\end{array}$ & $(0.148)$ & $\begin{array}{l}-0.847 \\
-0.078\end{array}$ & $(0.355)^{*}$ \\
\hline & $\mathrm{R}$ & $\begin{array}{l}0.053 \\
0.007 \\
\end{array}$ & $(0.061)$ & $\begin{array}{l}-0.127 \\
-0.013 \\
\end{array}$ & $(0.040)^{* * *}$ & $\begin{array}{l}-0.013 \\
-0.001 \\
\end{array}$ & $(0.084)$ \\
\hline & $\begin{array}{l}n \\
\text { LL/AIC }\end{array}$ & \multicolumn{2}{|c|}{$\begin{array}{c}290 \text { [58inds] } \\
-59.00 / 124.00\end{array}$} & \multicolumn{2}{|c|}{$\begin{array}{c}900 \text { [180inds] } \\
-148.05 / 302.10\end{array}$} & \multicolumn{2}{|c|}{$\begin{array}{c}320 \text { [64inds] } \\
-40.99 / 87.99 \\
\end{array}$} \\
\hline \multirow[t]{4}{*}{ Cavities } & C-pay & $\begin{array}{l}-0.934 \\
-0.193\end{array}$ & $(0.202)^{* * * *}$ & $\begin{array}{l}-0.547 \\
-0.130\end{array}$ & $(0.132)^{* * *}$ & $\begin{array}{l}0.267 \\
0.066\end{array}$ & $(0.240)$ \\
\hline & A-pay & $\begin{array}{l}-0.042 \\
-0.009\end{array}$ & $(0.177)$ & $\begin{array}{l}0.174 \\
0.041\end{array}$ & $(0.129)$ & $\begin{array}{l}-0.062 \\
-0.015\end{array}$ & $(0.230)$ \\
\hline & $\mathrm{R}$ & $\begin{array}{l}-0.003 \\
-0.001 \\
\end{array}$ & $(0.047)$ & $\begin{array}{l}0.012 \\
0.003 \\
\end{array}$ & $(0.032)$ & $\begin{array}{l}-0.013 \\
-0.003 \\
\end{array}$ & $(0.061)$ \\
\hline & $\begin{array}{l}n \\
\text { LL/AIC } \\
\end{array}$ & \multicolumn{2}{|c|}{$\begin{array}{c}260 \text { [52inds] } \\
-86.89 / 179.78\end{array}$} & \multicolumn{2}{|c|}{$\begin{array}{c}505 \text { [101inds] } \\
-186.66 / 379.31\end{array}$} & \multicolumn{2}{|c|}{$\begin{array}{c}155 \text { [31inds] } \\
-58.19 / 122.38 \\
\end{array}$} \\
\hline
\end{tabular}

Coef.: coefficient, dy/dx: marginal effect, SE: standard error of coefficient ***: $\mathrm{p}<0.001, \quad * *: \mathrm{p}<0.01, \quad *: \mathrm{p}<0.05$

C-pay: Co-payments (unit: 1000yen), A-pay: Advance payments (unit: 1000yen), R: Days required for reimbursements (unit: 10day), n' : Sample number in case that seeking treatment depends on payment terms (number of people (inds) times 5 answers), LL: Log-likelihood, AIC: Akaike's information criterion 
Table 9. Co-payment for every 1,000 yen in advance payment in relation to decisions regarding whether to seek treatment

\begin{tabular}{|l|c|c|c|}
\hline & Households on welfare & $\begin{array}{c}\text { Other low-income } \\
\text { household }\end{array}$ & $\begin{array}{c}\text { Middle-income } \\
\text { household }\end{array}$ \\
\hline $\begin{array}{l}\text { Themselves: } \\
\text { High-blood pressure }\end{array}$ & 188 yen & 131 yen & n.s. \\
\hline Themselves: A fever & n.s. & 122 yen & n.s. \\
\hline $\begin{array}{l}\text { Themselves: } \\
\text { Lower-back pain }\end{array}$ & 237 yen & 110 yen \\
\hline $\begin{array}{l}\text { Themselves: } \\
\text { Having difficulty falling asleep }\end{array}$ & n.s. & 127 yen & 134 yen \\
\hline $\begin{array}{l}\text { Their children: Rough skin } \\
\text { Their children: A fever }\end{array}$ & n.s. & 130 yen & 239 yen \\
\hline Their children: Vomiting & n.s. & n.s. & n.s. \\
\hline Their children: Cavities & $270 y e n$ & n.s. & $229 y e n$ \\
\hline
\end{tabular}

n.s.: Coefficients of advance payments are not significant

on the medical condition and the household income. There was a sense in which such decisions were influenced by the importance of medical care as perceived by the survey respondents, for example, in case of low-income households and their own symptoms are considered, advance payment controls that medical care is received or not.

Among all household groups, a relatively high percentage of participants would change their decision regarding medical care in response to the terms of co-payments and advance payments with respect to all the medical conditions that they themselves may experience, and regarding rough skin and one-time vomiting that their children may experience. A relatively low percentage of them would change their decision with respect to their children's fevers and cavities. As regards children's fevers and cavities, except cavities of children from lowincome households, advance payments incorporated into the model resulted in coefficients that were not significant. Thus, as far as these medical conditions were concerned, advance payments were perceived differently from other forms of cash spending, meaning that the participants believed that seeking medical care was important for such conditions.

Other research cases have also captured situations where the demand for medical care goes down due to an increase in co-payment rates (e.g. Suzuki et al. 2000) ${ }^{10)}$ and the importance of the co-payment ratio varies by the severity of the imagined symptoms. In Fukuda et al. (1999) ${ }^{11}$, the importance of co-payments in choosing a medical facility was lower for gastrointestinal symptoms than for the common cold. In Ii et al. (2002) ${ }^{12)}$ (Survey design and treatment of individual attributes and results on colds are common to Ii et al. 199913), increased co-payment rates led to lower rates of seeking medical care for colds, stiff shoulders and neck muscles, back and hip pain, constipation/ diarrhea, eye strain, and skin irritation, while no effects on medical visits were detected for hay fever, stomach pain and lethargy, headaches and menstrual cramps, athlete's foot and fish eye, injuries, and bruises and sprains. In this case, the impact of co-payments on medical visits was not significant for six of the thirteen diseases, further highlighting the fact that the impact of co-payments was symptom dependent.

In addition, study of Kawaguchi et al. (2015) ${ }^{14)}$ a threshold between "1,000 yen" and "5,000 yen," which is the fixed amount of co-payments in the case of first medical care in minor symptom, where the utility value of the 
behaviour changed from positive to negative. On the other hand, our study only shows a maximum co-payment of up to 4,800 yen (however, this is not an assumption for first medical care). Therefore, the impact of the copayments on medical care decisions may become even more pronounced if the amount is actually raised further.

The effect of reimbursement on reducing medical visits, especially with regard to one's own symptoms, is consistently seen in low-income households. From the opposite perspective, as seen in Zhong. (2011) ${ }^{15)}$, the group most likely to be promoted by same-day reimbursement appears to be in the middle of the income bracket. If the situation is similar to that of welfare households in Japan because the low-income group in this case is subject to the low co-payment rate system in China, the result of this study suggests that the effect of reimbursement on medical consultation is manifested in the group that is less likely to benefit from the system and does not have a high income. It is common with our study.

With regard to children's health care visits, observational study of Landsem et al. (2018) ${ }^{16)}$ analyzed the 10-20 year old age group, under 16 years of age with no co-payment and over 16 years of age with co-pay, respectively, and found that the effect of the co-pay system reduced the number of seeking general medical care by $10-15 \%$. On the other hand, the results of our study show a $21-34 \%$ decrease in the number of cares for excepting children's cavities due to an increase in co-payments of 1,000 yen from the average setting of the burden.

In the perspective of WTP (Willingness to Pay) for each medical condition, in a study using a conjoint analysis by Johnson et al. $(2000)^{17)}$, low values were taken for relatively mild symptoms of the nose and eyes, and high values were taken for symptoms such as heart and breathing. In our study, there was a relatively small reluctance to seeking medical care due to increased co-payments for hypertension in themselves and cavities in their children, but the effect of co-payments was not significant only for cavities in children at middle-income household. The large and small ranges of the impact of co-payments look different in each pattern of analysis.

\section{(2) Limitations of the research and subsequent observations}

Our study was conducted online. Thus, it is possible that the survey population is somewhat skewed towards younger people, and that decisions of elderly people who do not use the internet might not have been adequately considered. In addition, the research participants were chosen based on household types, and were not controlled based on the age or gender of the heads of households or household members. Thus, elements likely to be affected by the respondents' attributes, such as decisions regarding medical care based on individuals' physical conditions, must be viewed with these limitations in mind.

The information obtained by our study constitutes cross-sectional data of a particular point in time. No followup studies were conducted. For this reason, the research is not based on people's actual behaviour. Rather, the participants provided their answers in response to hypothetical situations.

There are also concerns that, because of the nature of this survey, the respondents might have been chosen among people who had more free time than the general population. Even so, depending on the medical condition, the same monetary value assigned to an increase in co-payments was assigned to the time and labour associated with cash reimbursements. This means that the participants may have taken into consideration their opportunity costs.

This study may have yielded certain insights regarding the relationship between reimbursements and people's decision with respect to medical care. However, the relationship between reimbursements and people's overall health must still be examined going forward.

\section{Note}

1 However, for people 75 or above, called the 'latter-stage elderly', approximately $90 \%$ of medical expenses are covered by the working generations (who are covered either by the national health insurance programme or employer-sponsored programmes). Expenses for those 65 or above and 74 or younger, the 'early-stage elderly', are adjusted based on their contributions.

2 The number " 1 " is assigned to cases where respondents say that they would seek medical care for themselves 
and for their children, and " 0 " to cases where respondent say that they would not.

\section{Acknowledgements}

This research has received funding from a Fiscal 2018 subsidy programme aimed at helping people with financial difficulties find employment (a social welfare promotion project of the Ministry of Health, Labour, and Welfare).

\section{References}

1) Newhouse JP and the Insurance Experiment Group. Free For All? Lessons from the RAND Health Insurance Experiment. Part 3, Effects of Cost Sharing on Health Outcomes. Cambridge: Harvard University Press. $1993: 183-306$

2) Kiil A and Houlberg K. How does copayment for health care services affect demand, health and redistribution? A systematic review of the empirical evidence from 1990 to 2011. Eur J Health Econ. $2014 ; 15: 813-828$

3) Keeler EB, Sloss EM, Brook RH, Operskalski BH, Goldberd GA and Newhouse JP. Effects of Cost Sharing on Physiological Health, Health Practices, and Worry. Health Services Research 1987 ; 22 : 279-306

4) National Federation of Health Insurance Societies, The social security study group. KENPOREN KAIGAI IRYO HOSHO. $2014 ; 101: 1-36$

5) Nay O, Béjean S, Benamouzig D, Bergeron H, Castel P and Ventelou B. Achieving universal health coverage in France: policy reforms and the challenge of inequalities. Lancet. $2016 ; 387: 2236-2249$

6) Nagamine Y and Kondo K. Shakaihokenjyunpo - Journal of Social Security Policy. 2016 ; $2652: 16-22$

7) Iwamoto C. Vertical externality of public finance as seen in local governments' medical subsidies: Focusing on the medical subsidy system for infants. Public Choice Studies. $2010 ; 54: 41-54$

8) Takaku R and Bessho S. Do benefits in kind or refunds affect health service utilization and health outcomes? A natural experiment from Japan. Health Policy. 2017 ; $121: 534-542$

9) Chiba S, Iwamoto T, and Okamoto S. A study on the conjoint analysis. Journal of Tokyo University of Information Sciences. $1997 ; 11: 137-154$

10) Suzuki W and Ohkusa Y. Conjoint Analysis for the Demand of Health Care related to Common Cold. Journal of health care, medicine and community. $2000 ; 10(1): 125-144$

11) Fukuda T, Kinoshita H, Takemura S and Yamaki S. A Survey Study Using Conjoint Analysis of Patients' Preferences for Medical Institutions. Hospital administration. $1999 ; 36: 156$

12) Ii M and Ohkusa Y. Economic Analysis of Demand for Medical Services. Nikkei Inc. 2002

13) Ii M and Ohkusa Y. Is There Any Substitution Between Medical Servicesand Over-the-Counter Medications in the Case of the Common Cold? -Analysis Based on an Original Survey-. ISER Discussion Paper. 1999 ; 478

14) Kawaguchi $H$ and Sugawara $T$. Research on measurement of hypothetical utility values for outpatient visits in large hospitals. Seijyo economic research. $2015 ; 210: 163-196$

15) Zhong H. Effect of patient reimbursement method on health-care utilization: evidence from China. Health Econ. $2011 ; 20$ : 1312-29.

16) Landsem MM and Magnussen J. The effect of copayments on the utilization of the GP service in Norway. Soc Sci Med. 2018 ; 205 : 99-106.

17) Johnson FR, Banzhaf MR and Desvousges WH. Willingness to pay for improved respiratory and cardiovascular health: a multiple - format, stated - preference approach. Health Economics. $2000 ; 9: 295-317$ 